\title{
RUY
}

\section{Homem de Gênio e Homem de Bem (*)}

\author{
A. de Sampaio Doria
}

Nas comemorações do centenário de Ruy, a Faculdade de Direito de São Paulo, onde êle se diplomou, não cede nem à Baía, que o viu nascer, a primazia no entusiasmo e na glorificação do Mestre sem igual. As festividades com que, nesses dias de surpresas, se procura avivar a superioridade de Ruy, não se podem em rigor ter na conta de homenagem. Empalidece de sentido prestar homenagem a Ruy: não se elogia o sol; a êle se agradece o calor e a vida que nos prodigaliza. Nós é que nos homenageamos a nós mesmos, com reconhecê-lo nos alcantis do gènio, e no primado do coração, singular na estirpe dos super-homens, com que a humanidade se vem fazendo digna de sobrevivência.

A capacidade de admiração não é prato do dỉa, sem dúvida, entre os néscios e os narcisos, aqueles por incapazes, e êstes por vaidosos. Os que, porém, não vivem mordendo-se de inveja, não regateiam louvores ao merecimento alheio. Quando o valor pessoal não é, apenas, dádiva da natureza, senão também fruto do trabalho, porque ressalvas, onde não cabem? porque comparações que amesquinhem? porque avarezas, quando há sobras?

(*) Aula de abertura do curso de 1949 
Quando se contempla a figura singular de Ruy, é moda evocar logo Cícero, o cidadão do Senado Romano, para encadeiar Ruy numa órbita de satélite. Quando se quer considerar, em Ruy, o homem de estado, parece obsessão sugerir Rio Branco, o nume tutelar da pátria, no Itamaraty, para cegar, em Ruy, a visão com que antecipou, aos olhos das nações, as bases do direito, na politica da era atômica, que começou em Hiroshima. Quando se mede a projecção de Ruy no cenário da política, a balda é vir à baila Épitácio, o orador magnifico, para fraquear as azas da eloqüência aỉada, com que Ruy superou, nos vôos da imaginação, na sagacidade dos raciocínios, sem desamor à perfeição da forma, a quantos oradores já espiritualizaram a humanidade.

Cessem, porém, na celebração do centenário de Ruy, as comparações da inveja, e as mesquinhezas na incapacidade de admirar. Considere-se Ruy, tão só Ruy, em si mesmo, e nada mais.

Nos cimos da inteligência, $p$ nas eminências do sentimento, entre os insuperáveis, na glória do gênio, e na bem-aventurança da bondade, cada povo parece abençoado com a flor, que só uma vez na vida floresce, de um sem-igual, que não se repete. A Grécia, na constelação de seus maiores, alça, em Homero e Aristóteles, os prodigios que por si só a eternizaram. A Inglaterra, acima de seu império, se gloria de Shakespeare, que lhe sobrevive às quedas do poder e da riqueza. Não se muiltiplicou, no espírito imortal da Itália, o milagre de Dante. Goëthe sublimou sem rival na Alemanha. Quem, na França, empanou jamais o brilho a Hugo na arte, ou a Pasteur na ciência? A Espanha, com D. Quixote, se ufana, com razão, de Cervantes. E o bem amado Portugal elegeu, primus inter pares, o seu e nosso Camões.

Também o Brasil subiu até Ruy, e perdeu-se o molde, para nunca mais.

Singular foi êle, desde o alvorecer de esperanças na Baía, até o ocaso de sua morte em Petrópolis. Entre êstes dois extremos, sua diretriz na vida foi, sempre, uma cons- 
tante da verdade ao bem. Alcindo Guanabara lhe simbolizara a vida por:

"uma recta traçada entre a liberdade e o direito."

Não se desviando nunca dessa recta, de si mesmo confessou, já com a sombra da eternidade nos olhos:

"Ensinei com a doutrina e o exemplo, mas ainda mais com o exemplo do que com a doutrina, o culto da legalidade, as normas e o uso da resistência constitucional, o desprêzo e o horror da opressão, o valor e a eficácia da justiça, o amor e o exercício da liberdade."

Porque sempre:

"Estremeu a pátria, viveu no trabalho e não perdeu o ideal."

Tendo Deus acendido, "em sua cabeça, um vulcão", na frase de José do Patrocínio, fez êle dêsse vulcão forças benfazejas, em benefício da pátria e da humanidade, posto dêste apostolado mais não lograsse que colheita escassa e melancólica.

Mas estava predestinado.

Ainda na adolescência, grandes lições paternas lhe abriram as portas ao futuro, numa iluminada atmosfera de grandeza evangélica. Tinha Ruy 15 anos, quando terminou os preparatórios; e só aos 16 podia matricular-se na Faculdade de Direito, que o atraia. Não faltaram sugestões para o arranjo de uma certidão graciosa, com mais um ano de idade. Era e é comum. Atalhou, porém, o pai com esta lição:

“Não hás de entrar na vida pública por uma mentira. Perderás um ano e te aperfeiçoarás no alemão." 
Para repelir a falsificação que a tantos parecia e parece inocente, ou hábil, não precisava o filho que lhe ministrassem a lição. A palavra do pai exprimia a índole que the bafejara o berço ao filho.

No colégio, que acabava de deixar, já dera mostras de correcção impecável, a ponto de, sessenta anos depois, testemunhar seu professor, Carneiro Ribeiro:

"Era sempre o primeiro a correr à sala de estudos, a desempenhar-se de todos os deveres escolares. No procedimento, sempre discreto, exacto, sensato, e exemplaríssimo. Na moralidade e pureza de costumes, sempre modelar."

Eram estas as esperanças da meninice, que a mocidade inflamou em propósitos generosos, sempre renovados, apesar das desilusões que não tardaram em lhe amargurar a existência.

Falo de uma cátedra, aos moços, provàvelmente pela última vez. Devo, por coerência de meus hábitos, usar com êles a linguagem do professor, que explica e persuade. Por isso, se, ao sairdes daqui, năo virdes, em Ruy, a verdade contra os êrros, a argúcia contra os sofismas, o direito contra os crimes, a liberdade contra as opressões, a justiça contra as iniqüidades, a conciência contra o egoismo, o ideal em acção, tereis perdido vosso tempo, e eu o meu.

Os professores desta Casa vos falarão, êste ano, em comemoração centenária, na cátedra e na Revista, sôbre Ruy, o jurista, Ruy, o estadista, Ruy, o orador, Ruy, o enciclopédico, Ruy, o batalhador pelo ideal. Em prefácio do que irão celebrar, me designaram para uma visão de conjunto, no que mais a propósito vos pudesse servir, nas lides do direito, em que pondes vossa esperança, nas lutas pela liberdade, que a dignidade vos impõe, na faina incessante do dever, seja como for, e dê no que der. 


\section{COM RUY NINGUEM ERRA}

Para bem começar, em verdade vos digo que com Ruy ninguém erra. Houve quem, certa vez, dissesse que, "com Ruy, nem para o céu". Mas êsse terminou, na hora do perigo, solidário com êle, para o inferno das lutas amargas, em busca do direito.

Bem haja o govêrno que the vem publicando as obras, para que as gerações de hoje e do futuro aprendam:

“o amor da liberdade, servido pela independência e pela desambição."

Aprenderão que o direito, como dizia êle na "Imprensa":

"não tem acepção de pessoas, interesses ou opiniões. Na ínfima das criaturas, na mais aviltada, na mais perdida, projeta os seus raios imaculados, como o sol resplandecendo, com a mesma pureza., no cristal do oceano, ou no lodo dos charcos. Quanto mais se rebaixa o ente humano, quanto mais se alonga da sua origem, quanto mais abandonado parece do céu e da terra, mais jús tem a essa proteção da justiça, que não conhece precipúcios nem alturas, não varia dos palácios às choupanas, dos tronos às enxovias. Êle acompanha o réu no tribunal, o prêso no cárcere, o próprio condenado no patíbulo, enquanto, com o último alento ainda não respirado, the reste a hipótese de um apêlo, a emergência de um êrro descoberto, o imprevisto de uma reabilitação extrema."

Não haveis de esquecer de que:

"a liberdade é a condição da pátria, é a consciência, é o homem, é o principio divino do nosso existir, é o único bem, cujo sacrificio a pátria não nos pode reclamar, senão deliberada ao suicídio, com o que o amor da pátria não nos permitiria condescender." 
E mais:

"Quando uma nação se resigna ao cativeiro, abdicando inteiramente a vontade de ser dona de si mesma, a pátria recolhe-se ao fundo das conciências revoltadas, ou se traslada para o exilio das minorias insubmissas, cuja virtude vai alimentar, no ambiente da hospitalidade estrangeira, o lume da ressureição que se extinguiria abafado na estreiteza de um ninho de escravos. Sim, porque a pátria não é uma expressão geográfica, nem as maravilhas da criação, que a revestem, nem a multidão humana, que a povoa. 0 território vem a ser apenas o quadro da existência moral, que expira com a supressão da liberdade."

Ouvireis êste credo político, hoje sem pregadores, sem seguidores, tão desprezado e tão de rasto:

“Creio na liberdade onipotente, criadora das nacões robustas; creio na lei, emanação dela, o seu órgão capital, a primeira das suas necessidades; creio que, neste regime, não há poderes soberanos, e soberano é só o direito, interpretado pelos tribunais; creio que a própria soberania popular necessita de limites, $e$ que êsses limites vêm a ser as suas constituições, por ela mesmo criadas, nas suas horas de inspiração juridica, em garantia contra os seus impulsos de paixão desordenada; creio que a República decai, porque se deixou estragar, confiando-se ao regime da força; creio que a Federação perecerá, se continuar a não saber acatar e elevar a justiça; porque da justiça nasce a confiança, da confiança a tranqüilidade, da tranqüilidade o trabalho, do trabalho a produção, da produção o crédito, do crédito a opulência, da opulência a respeitabilidade, a duração, o vigor; creio no govêrno do povo pelo povo; creio, 
porém, que o govêrno do povo pelo povo tềia a base da sua legitimidade na cultura da inteligência nacional pelo desenvolvimento nacional do ensino, para o qual as maiores liberdades do Tesouro constituirão sempre o mais reprodutivo emprêgo da riqueza pública; creio na tribuna sem fúrias e na imprensa sem restrições, porque creio no poder da razão e da verdade; creio na moderação e na tolerância, no progresso e na tradição, no respeito e na disciplina, na impotência fatal dos incompetentes e no valor insuprível das capacidades."

Não tereis ilusões sôbre govêrno de força, de arbítrio, de violências. Ouvi-o, neste reverso do credo:

"Rejeito as doutrinas de arbítrio; abomino as ditaduras de todo gênero, militares ou cientificas, coroadas ou populares; detesto os estados de sítio, as suspensões de garantias, as razões de Estado, as leis de salvação pública; odeio as combinações hipócritas do absolutismo dissimulado sob as formas democráticas e republicanas; oponho-me aos govêrnos de ignorância; e quando esta se traduz pela abolição geral das grandes instituições docentes, isto é, pela hostilidade radical à inteligência do país nos focos mais altos de sua cultura, a estúpida selvageria desta fórmula administrativa impressiona-me como o bramir de um oceano de barbaria ameaçando as fronteiras de nossa nacionalidade."

Vêde êsse traçado de uma vida nobre:

"Nunca dirigi uma violência, nunca apoiei um atentado, nunca fui pela fôrça contra o direito, nunca fui pela injustiça contra a legalidade. Não conspirei nunca; condenei as conspirações, embora o ódio polí- 
tico por mais de uma vez tentasse nelas envolver-me."

Lembrar-vos-ei de que:

$a^{\text {" }}$ república não é uma série de fórmulas, mas um conjunto de instituições, cuja realidade se afirma pela sua sinceridade no respeito às leis e na obediência à justiça."

A vida pública só será digna, se correr:

"com a lei e dentro na lei, porque, fora da lei. não há salvação."

Meditae nesta norma de uma vida militante sadia:

"Toda vez que uma opinião lícita for convertida em crime, eu, em revolta com os inquisidores politicos, me inscreverei na opinião perseguida."

E, mais, atentando-se que a solidariedade sem discernimento pode vir a ser cumplicidade no êrro e no crime:

"Não sou dos que acompanham os govêrnos a despeito de tudo. Não. A despeito de tudo, só acompanho a minha conciência. Mas, estando com ela, então o amigo com que me acho, a causa, a que sirvo, me tem a seu lado."

Porque:

"Todo poder ilegitimo nasce com a morte no seio, para viver morrendo e matando."

E'm verdade:

“a República precisa ser conservadora a um tempo contra o radicalismo e contra o despotismo, contra as utopias revolucionárias e contra as usur- 
pações administrativas, contra a selvageria anárquica das facções, e contra a educação inconstitucional dos govêrnos."

Aprendamos, com o Mestre, que:

"a suprema santificação da linguagem humana, abaixo da prece, está no ensino da mocidade. o lavrador dêste chão deve amanhá-lo de joelhos. Crede que me acho realmente sob esta impressão, como se, ao receber dos braços de minha companheira um filho recem-nascido, uma voz interior me segredasse: purifica o teu hálito, que lhe vais insuflar a vida ou a morte."

E Ruy foi, desde moço, professor. Ensinou sempre, mais com o exemplo que com a doutrina, o amor da verdade, e o amor do bem. Sua prẻgação sôbre as instituições constitucionais foi:

"um curso de lições de coisas, para lhes facilitar o uso, pondo-as ao alcance de todos."

Não acabaria tão cedo, se quisesse recoỉher, em seu ensino, as joias das idéias cintilantes, dos princípios generosos, dos ideais imaculados, por que viveu, sofreu e morreu.

Seu ministério foi um apostolado, a espera de historiadores, para revelar em ordem sua vida. Nêsse apostolado, Ruy não foi apenas o professor, como há tantos. Não só o gênio que doutrinava; mas o santo que praticava a doutrina doutrinada.

Não exagero, nem regateio. Senão, vejamos.

\section{GÊNIO}

Sabeis ao certo o que é a superioridade no homem? Talvez estejais persuadidos de que sim, só com supor que superior é o acima do normal. 
Mas já meditastes no que seja, realmente, normalidade? Já vos fizestes a vós mesmos a pergunta: que vem a ser normal?

Não se confunde o homem normal com a média social, o médio, o comum, ou medíocre, em certa civilização, lugar e época. Nas fases de corrupção geral, como a que precedeu a queda do Império Romano, e a que, desde a primeira guerra mundial, vem solapando, no mundo, as bases da moral e do direito, da honra e da justiça, da palavra e da confiança, a média que se apure, ě de corruptos, degenerados, anormais.

Normal é, em verdade, o homem que, dentro das leis que regem a vida do indivíduo e da sociedade, sobrevive por si mesmo. E só sobrevive quem se adapte a estas leis. Pôr-se em rebeldia com as leis de conservação da vida humana, é caminho do suicídio.

Para que a criatura se adapte às leis de conservação da vida individual e social, preciso é, primeiro, que seja capaz de as apreender e cumprir. Dai, serem o imbecil e o criminoso anormais.

$E$, então, de duas, uma. Ou o homem é capaz de discenir entre as condições positivas e as negativas da vida, e, sob o aspecto intelectual, é normal, porque, se veio ao mundo, é para que viva; ou o homem, ao contrário, não é nem ao menos capaz de delimitar entre o que respeita, e o que destroe a vida do indivíduo e da sociedade, quanto mais de respeitar as condições positivas e repelir as negativas, e viverá destruindo-se a si mesmo e aos outros, e será demente, ou bandido.

O lugar e a ocasião não permitem desenvolvimentos. Mas, numa síntese compreensiva, normalidade é a capacidade de adaptação individual às leis da vida.

Quando a capacidade de adaptação de um homem supera a média de sua raça, de sua gente, de seu meio, êste homem é supernormal, ou superior. Se abaixo da média, o indivíduo é subnormal, ou inferior. 
A superioridade orgânica é vigor, saúde, destreza. A superioridade intelectual é talento, e, quando o sumo gráu no poder de previsão, no poder da verdade, é gênio. A superioridade moral é abnegação, e, quando o sumo gráu na prática do bem, é santidade.

Haverá gênios que não sejam santos, como Napoleão. E santos que não são gênios, como é de regra. Só por milagre se encontrará, na mesma criatura, o que edifique para sempre em beleza e verdade, è o que, ao mesmo tempo, sacrifique sua vida por amor de seus semelhantes, por devoção a princípios, na prática do bem pelo bem.

Quando uma criatura percebe tudo de pronto, certo e muito; quando tudo memorize, sem esquecer até minúcias; quando lhe rasga a imaginação horizontes insondáveis; quando o verbo com que se exprima, se transluz em clareza, e encanta pela beleza; quando não há trincas na lógica dos raciocínios para a revelação e a prova das verdades; quando tudo isso converge numa só pessoa, não há negar que estamos diante de uma capacidade excepcional. Que mais se há de exigir para a genialidade, além da suma capacidade de prever?

Os repentes, as explosões, o deseqüilíbrio? A criação, a invenção, a decifração de mistérios?

Ruy atingiu, na segurança, na profundidade, e nos longes da inteligência, ráias insuperáveis. Foi um prodígio de memória. Verbo como nenhum outro. Argúcia que vê mais e melhor que a média. Raciocínios maravilhosos. Imaginação surpreendente.

Em Haya, para onde as nações enviaram sumidades da inteligência e da cultura, Ruy foi, pelo gênio com que se houve, e pela sabedoria que revelou, o maior de todos.

Entre os membros da conferência, testemunha Stead, o jornalista daquela assembléia de notáveis:

"não tardou muito que se esvanecessem as dúvidas sôbre a qualidade e o calibre do representante do Brasil. Desde as primeiras assentadas, tomou 
parte o Dr. Barbosa em todos os debates mais relevantes, com uma compostura, uma calnia a uma imperturbalidade, que, a priucípio, o tornaram objeto de zombaria e, ao depuis, de desgôsto. 'linhan vindo a sentir que o Dr. Barbosa era um combateate de primeira ordem. suja fôrça nunca se nostrava mais eficaz 'o que na investida. A mais de unn dos que o sallearam, deu êle a experimentar de tal modo êsse predicado, que nunca mais se animaram a tocar-lhe."

E acrescenta:

“As duas maiores fôrças pessoais da Conferência foram o Barão Marshall, da Alemanha, e o Dr. Barbosa, do Brasil. Atrás do Barão Marshall, porém, se erguia todo o poder militar do império germânico, alí bem à mão, de contínuo aos olhos de todos os delegados. Atrás do Dr. Barbosa estava apenas uma longínqua república desconhecida, com ưm exército incapaz de qualquer movimento militar, e uma esquadra ainda por existir... Apesar disto, ao acabar a Conferência, o Dr. Barbosa pesava mais do que o Barão Marshall. Maior triunfo pessoal na recente Conferência, nenhum dos seus membros o obteve; e tanto mais notável foi, quando o alcançou êle por si só, sem nenhum auxílio estranho. Aliados não tinha o Dr. Barbosa; tinha muitos rivais, muitos inimigos, e, contudo, vingou aquele cimo. Foi um imenso triunfo pessoal, que redundou em crédito para o Brasil."

Como Stead, Lapradelle, maravilhado com a ciência e a eloqüência de Ruy, nos dá êsse testemunho:

“Antes de tudo, a eloqüência. Foi um assombro. Corria malignamente, nas delegações, o rumor de que 
os belos discursos de Ruy Barbosa eram longamente preparados, decorados e recitados. Um dia, um dos presidentes tentou deter Barbosa, alegando que a questão de que êle queria tratar, inteiramente política, estava fora do programa duma conferência, exclusivamente jurídica. E o primeiro delegado do Brasil, num improviso magnifico, mostrou que, entre o direito e a política, não podia, não devia, nas relações internacionais, haver jamais separação. Outro dia, quando o maior dos oradores norte-americanos, Choate, acabara de pronunciar um eloquente discurso em inglês, Barbosa se levantou antes de ser feita a tradução.

- Espere que o intérprete traduza, lembraram-lhe.

- Que êle espere acabar eu o meu discurso. Traduzirá os dois.

$\mathrm{E}$ passou a responder em inglês tão brilhantemente, como o fizera em francês.

"Mas em Haya, continua Lapradelle, aprendeu também a Europa, por Barbosa, que, no Brasil, a ciência igualava a eloqüência. Tinha lido todos os livros. Todas as doutrinas conhecia. Jurisprudência, êle as tinha anotado todas. Enfim a Europa aprendeu que esta ciência, esta eloqüiência, o Brasil sabia pô-las a serviço das mais preciosas causas: a inviolabilidade da propriedade, o desenvolvimento do arbitramento, a igualdade dos Estados. Na sala dos Cavalheiros, séde da Conferência, era, sob sua aparência franzina, frágil e quase exígua, um dos maiores cavalheiros da idéia de justiça e de paz. Graças a Ruy Barbosa, defensor do direito, o Brasil saiu engrandecido ante o mundo, da segunda Conferência de Paz." 
Não varia de conceito o embaixador dos Estados Unidos em Paris, Robert Bacon, quando lhe dizia:

"Vossa eloqüência e vossos triunfos em Haya atrairam a atenção do mundo civilizado. Não são sómente as duas Americas, é o mundo inteiro que deve aproveitar, para sempre, de vossos nobres esforços."

E fez Hill, o delegado dos Estados Unidos à Conferência, esta previsão:

"Se vós, Sr. embaixador, sois a alma do Brasil, se as vossas idéias, tão claras, tão justas, tão nobres, tão modernas, predominam em vossa pátria, eu lhe predigo, no futuro, uma prosperidade sem limites, assim como o respeito do mundo inteiro às suas leis e instituições."

Eis Ruy como era reconhecido na Europa e nos Estados Unidos. Silenciemos o testemunho de casa, que pode ser taxado de patriotice. Mas os dos estrangeiros a quem êle contrariou, e levou de vencida, parecem madrigais. Dos testemunhos de casa, apienas esta narração sôbre o incidente com Martens, um dos presidentes da Conferência, e a que se refere Stead:

"Eu estava, declara Rodrigo Octavio, na sala, sentado num banco sôbre a parede. Levantei-me também, e foi êsse um dos momentos de mais viva emoção de minha vida. Senti que uma grande cena se ia passar, e era o nome do Brasil, o prestígio do Brasil, a honra do Brasil, que estavam em cena. Num acentuado movimento de atenção, todos, na espectativa de um escândalo, pelo menos de uma estralada, se voltaram para o orador que, como presidente honorário da Primeira Comissão, tinha assento na própria mesa, à direita do presidente, cir- 
cunstância que lhe dava ainda, no momento, maior realce."

"Martens, ao lado de Ruy, mantinha a cara amarrada, e mostrava, de princípio, manifesto nervosismo.

"E Ruy, pequeno, humilde, com voz sumida, que depois se elevou e se tornou clara, começou a proferir êsse discurso qư foi, por certo, a peça oratória mais notável que a Conferência ouviu, e lhe proporcionou o seu momento de maior brilho intelectual... Ruy Barbosa, pequeno de estatura, modesto, quase tímido no trato, foi crescendo aos olhos da assistência, à proporção que, com o maior desassombro de si mesmo, com a mais subida eloqüência, proferia sua magnífica oração, e seguiu, depois do incidente, crescendo de tal modo, que acabou impondo-se à admiração de seus pares."

A inspiração dos princípios da liberdade, do direito e da justiça, em que a eloqüência e a ciência se conjugavam, tinha sido, e continuou, até às věsperas de sua morte, a constante na vida pública de Ruy. Da eloqüência, lêde a réplica à investida de Ramiro Barcelos sôbre as finanças do Govêrno Provisório, quando Ruy Ministro da Fazenda; foi o improviso da eloqüência mais vibrante, de que se tem noticia.

Da ciência, considerai a passagem de Ruy pelo Ministério da Fazenda do Govêrno Provisório. A inteligência de Ruy, aliada à sabedoria e ao senso das realidades, devassou os segredos das finanças, com um poder de penetração apenas comparável ao que demonstrou mais tarde em Haya. $\mathrm{O}$ desastre financeiro que abalou os primeiros anos da República, e só começou a deter-se nos diques da política de Campos Salles, foi atribuido, pela ignorância, maledicência e ódio político, à administração de Ruy, quando Ministro da Fazenda do Govêrno Provisório. No entanto, a sabedoria de 
Murtinho, Ministro de Campos Salles, consistiu em restabelecer a providência de Ruy: o imposto em ouro.

"Se o programa financeiro de Ruy houvesse sido executado, declara Felisberto Freire, seu inimigo pessoal, já estariamos no regime metálico."

E Cincinato Braga reconhece:

"Quanto mais estudo o plano financeiro do Govêrno Provisório, mais me convenço de que a acção de Ruy foi genial."

São do Jornal do Commercio estas palavras sôbre a ruina financeira, chegada ao extremo em 1898, da qual:

"Só logramos sair, voltando àquilo que constitui a medida capital do programa Ruy Barbosa: o imposto em ouro:"

Realmente, nunca mais teve o Brasil a ventura de tão grande ministro, como Ruy no Govêrno Provisório. De seu gênio, outra cousa não se podia esperar. "O mal da República", afirmava Ramiro Barcelos, adversário de Ruy, foi nós, os historiadores, não termos compreendido a grandeza de Ruy."

Ainda que a característica do gênio fosse apenas a criação, ainda assim Ruy foi dos gênios mais profundos, que a humanidade já teve.

$\mathrm{Na}$ esfera dos fenômenos físicos e biológicos, Newton, Pasteur, Einstein descobrem leis que desfazem mistérios. A observação metódica e a longa paciência, e, às vezes, o acaso feliz, têm desvendado, desde há milênios, relações de causalidade nos fenômenos físicos. Onde, porém, mais se adensam as dificuldades, é no emaranhado dos factos que constituem o mundo moral. Enquanto na física se chega à maravilha diabólica da desagregação do átomo, na moral e 
no direito poucos passos de progresso têm sido possíveis, desde tempos quase imemoriais. As leis que regem as relações dos indivíduos e dos povos, são, mais do que as leis do mundo físico ou biológico, encobertas nas trevas do mistério.

Pois, nesta esfera de investigações, Ruy previu mais e melhor que o geral. Ruy criou, na inferência de leis, e foi genial.

Dentro do país, foi o criador do habeas-corpus, na amplitude da Constituição de 1891. Os entrevados na tradição de um habeas-corpus para a soltura, ou para não ser preso, ficaram retrógrados na reforma de 1926, ainda que, por consolação, admitissem, como admitiram, o mandado de segurança.

Más a garantia ampla do "dar-se-á o habeas-corpus sempre que o individuo sofrer, ou se achar em eminente perigo de sofrer, coacção ou violência, por ilegalidade ou abuso do poder", desapareceu na reforma de 1926. O mandado de segurança deixou espaços vazios, com sua morosidade prejudicial ao direito, líquido e certo, a que busque amparo.

Ainda dentro no país, seu gênio previu, nos êrros da Constituição de 1891, a guerra civil, que veio, e o falseamento da República, que a tem desmantelado.

Se tivesse a Constituinte de 1890 mantido, na Constituição que promulgou, o preceito de suceder o vice-presidente da República ao presidente também no primeiro biênio, como é da sabedoria e da experiência norte-americana, e, afinal, se adotou na Constituição ora vigente, não teriamos tido a revolta de Custódio de Mello, nem a guerra civil de 1893.

Se tivesse a constituinte de 1890 mantido o sistema de eleição presidencial, que Ruy propuzera, não teriamos assistido a estas duas calamidades : $10^{\circ}$ ) arrogar-se o Congresso Nacional, incumbido pela Constituição de julgar a eleição 
presidencial, a função de nomear o presidente em convenções prévias, juiz e parte na mesma causa; e 2. ${ }^{\circ}$ ) usurpar o Congresso à Nação sem defesa o direito de eleger seu magistrado supremo.

Lêde a Contestação Civilista de maio de 1910, para verificardes o confisco, desabusado e cinico, que então falsificou em república o caudilhismo da casaca, em mancebia com a farda, entronizado no Congresso.

Mas o embaixador de Haya não era a alma do Brasil; "suas idéias tão claras, tão justas, tão nobres, tão modernas" não predominaram em sua pátria, e, por isso, a predição do embaixador dos Estados Unidos à Conferência de Haya, de "uma prosperidade sem limites" ao Brasil, "assim como o respeito do mundo inteiro às suas leis e instituições", a predição falhou. O Brasil não merecia Ruy, e, mesmo hoje, mal o conhece, e, ainda assim, por ouvir dizer. As previsões de Ruy para a prosperidade do país, e para o respeito às suas instituições, não encontraram visão nos olhos cegos. nem eco nos ouvidos surdos, de sua gente.

Seu gênio, porém, não se limitou a leis sociais sôbre fenômenos do país. Fora do país, seu gênio revelou à ciência universal duas grandes leis de sabedoria profunda, para a consolidação da paz no mundo.

A primeira foi a lei da igualdade dos Estados soberanos perante o direito internacional. Na sub-comissão dos oito sábios, em Haya, Ruy sustentou, de começo só, e, por fim, com aplausos de todos, o princípio de igualdade dos Estados. Eis como Stead nos conta a batalha do gênio:

"Contra Ruy se erguiam todas as torças do mundo. Os outros delegados representavam mais de 800 milhões. e todos os exércitos e armadas efetivos do mundo. O Dr. Barbosa representava o Brasil com uma população de 25 milhões, um exército e uma armada incapazes de acção efetiva além de suas fronteiras ou de suas águas. Mas Ruy nunca 
trepidou nem esmoreceu. Campeão de um princípio em que acreditava fielmente, e avigorado por esta fé, não receava desiguldade. Após longa série de debates, teve a satisfação de ver os Estados Unidos acercar-se dêle. 0 princípio de darem-se os melhores lugares do Tribunal às potências mais fortes, foi renunciado. Todos os juizes teriam de ser eleitos, e todos os Estados, grandes ou pequenos, teriam voto igual."

Pareceu ao embaixador da França, na Conferência, Leon Bourgeois, que a vitória de Ruy revelava falta de diplomacia e ausência de senso prático. "Não compreendo", dizia êle a Rodrigo Octavio, que nô-lo relata, "êsse homem extraordinário."

"Com um pouco de diplomacia, de sua parte, ter-se-ia alcançado uma fórmula pela qual o Brasil... pudesse encontrar situação permanente no Tribunal de Justiça Internacional, e se engrandecer como Estado, dentro da organização política do mundo."

Defendendo intransigentemente o princípio da igualdade juridica dos Estados, Ruy Barbosa, continua Leon Bourgeois, arrebanhou prosélitos e venceu.

"Sôbre isto, não há dủvida. Mas o Brasil poderia ter saído desta Conferência o igual da França, o igual da Inglaterra, o igual dos Estados Unidos. Ruy Barbosa conjugou o melhor de seus esforços e os tesouros de seu saber, para conseguir que dêle saisse o Brasil o igual de Nicaragua, o igual de Honduras, o igual de Sião."

Mas Ruy, escreve João Mangabeira, o autor do melhor livro que já se escreveu sôbre Ruy, e do qual extraimos as traduções acima, (livro que deveria figurar onde quer que 
baja um lar brasileiro) Ruy não era o homem ordinário, para sacrificar um grande princípio moral a um passageiro interesse material", princípio definitivo, e hoje incontestável, "que Ruy levantou, sustentou e venceu, contra tudo e contra todos, com a flama, a fé e a intransigência dos apóstolos."

E' que Ruy, de Sancho tinha apenas o bom senso; mas de D. Quixote a sublimidade.

“Quando praticamos uma acção boa, diz êle na Contestação Civilista, não sabemos se é para hoje ou para quando. 0 caso é que os seus frutos podem ser tardios, mas são certos. Uns plantam a semente da couve para o prato de amanhã, outros a semente do carvalho para o abrigo do futuro. Aqueles cavam para si mesmos. Estes lavram para a felicidade dos seus descendentes, para o benefício do gênero humano."

A segunda lei em ciência social, que a Ruy se deve, é a da neutralidade vigilante e judicativa. Comunicou-a êle de uma tribuna, na Faculdade de Direito de Buenos Aires, em 1918, clamando ao mundo:

"Nos tempos de hoje, declara, com a internacionalização crescente dos interesses nacionais, com a permeação mútua que as nacionalidades exercem umas sôbre as outras, com a interdependência essencial, em que vivem, umas das outras, as nações mais remotas, a guerra jả não se pode insular nos Estados entre quem se abre o conflito. Suas comoções, seus estragos, suas misérias repercutem ao longe, sobre o crédito, o comèrcio, a fortuna dos povos mais distantes."

Diante desta interdependência que faz do convívio internacional um mundo só, a neutralidade nas guerras deixa 
de ser impassibilidade, para ser judicatura entre o direito e o crime.

“E' mister, tira Ruy a ilação, que a neutralidade receba uma expressão, uma natureza, um papel diverso do das outras."

E conceitua :

"Entre os que destroem a lei, e os que a observam, não há neuitralidade admissível. Neutralidade não quer dizer impassibilidade; quer dizer imparcialidade, e não há imparcialidade entre o delito e a justiça. Quando entre ela e êle existem normas escritas, que os discriminam, pugnar pela observância destas normas não é quebrar a neutralidade, é praticá-la. Depois que a violência pisa aos pés arrogantemente o código escrito, cruzar os braços é servi-la. Os tribunais, a opinião pública, a conciência não são neutros entre a lei e o crime. Em presença da insurreição armada contra o direito positivo, a neutralidade não pode ser insensibilidade, não pode ser o silêncio."

E remata:

"a neutralidade inerte e surda-muda cede a vez à neutralidade vigilante e judicativa."

Eis os dois princípios que Ruy criou na ciência do direito, e da politica, para bases futuras ao Super-Estado, que virá na era atômica, que se inicia. A previsão das conseqüências, a constância entre as causas e os efeitos nas relações dos povos entre si, Ruy as revelou, em linguagem nova, e tão persuasivamente, que Bartou, poderia dêle dizer com razão:

"Para a Pátria, êle é uma glória, para a Humanidade, uma conciência." 
Não acabaria tão cedo, se vos quizesse enumerar os rasgos de genialidade de Ruy, no mundo moral, onde pontificou.

\section{HOMEM DE BEM}

Devo, porém, indicar-vos, ainda, alguns factos, por onde se veja que, além de gênio, se alçara Ruy aos cimos da grandeza moral, à santidade possivel, na fragilidade inextirpável da natureza humana.

E' vezo gaguejar-se que Ruy foi um grande talento, cultura enciclopédica, e nada mais. Homem para uso externo. Nem siquer deixou obra sistemática, tudo disperso, ao sabor das ocasióes.

Não lhe estava realmente no feitio o espírito de sistema. Admitamos que a Constituição de 1891, de que foi o principal autor, não seja um sistema de direito público. E daí? Rastreia alguém, na peregrinação de Jesus neste mundo, sistema científico ou filosófico? Nem por isso deixou Jesus de ser, para a porção mais culta da humanidade, o filho de Deus entre os homens, para lhes revelar a verdade.

Dizer, porém, de Ruy, que era talentoso, culto, e nada mais, é uma destas calúnias atrozes, inconscientes, e, às vezes, estúpidas, que lhe foram semeando espinhos nos caminhos da vida. o que, acima de tudo, em Ruy, é de louvar, é exatamente a nobreza de seus sentimentos, a elevação moral de seus actos, a desambição das campanhas que travou, numa palavra: a sinceridade, o caracter, uma equação estável entre seu procedimento e súas convicções.

Dir-se-á que de convicções molestas, à maneira das raciais ou moscovitas, só desgraças irreparáveis se hão de esperar.

Mas o bom caracter é a recta entre o que se faz, ou se deixa de fazer, e as convicções, inspiradas no direito, na justiça, no bem. E' a premissa maior de um silogismo incômodo. 
Não se diga que a noção do bem é flutuante; o bem, em si mesmo, uma ficção. $O$ bem, de verdade, não é matéria opinativa, variável com o tempo e o espaço, nem tão pouco preconceito burguês, como balbuciam por bem os cínicos que o bem renegam.

O bem, em que a revelação divina, e a observação científica se dão mãos amigas, é invariável e constante. Em religião, o bem é a conformidade dos actos humanos com a vontade do Criador. Em ciência, o bem é a conformidade dos actos humanos com as leis de conservação a desenvolvimento do homem e da sociedade. Mas, sendo Deus o Criador do Universo, as leis da vida e desenvolvimento do homem e da sociedade, parcelas do Universo, são expressões permanentes da vontade de Deus, que os criou. Logo, no que há de essencial, o bem em religião é o bem em ciência. E, quando, acaso, a moral científica e a moral religiosa se contraponham, é que uma delas usurpa à outra a glória da bondade.

Em Ruy, mais que os rasgos de gênio, mais que a palavra de sábio, admira-se a encarnação viva do homem de bem. Viveu na paixão da verdade e na paixão do direito.

$\mathrm{Na}$ Oração aos Moços, bacharelandos desta Casa, dizia ter tido consôlo de haver dado ao país tudo que lhe estava ao alcance: "a desambição, a pureza, a sinceridade, os excessos de actividade incansável, com que, desde os bancos acadêmicos", serviu sua terra e sua gente. Pregou, demonstrou, honrou a verdade eleitoral, a verdade constitucional, a verdade republicana, embora sempre incompreendido e vencido. Nas lutas que travou, jamais o moveu a ambição do poder, jamais o despeito ou o ódio a seus semelhantes. Os maus só lhe inspiravam tristeza e piedade. Só o mal é que o inflamava em repulsa.

"Porque o ódio ao mal é amor ao bem, e a ira contra o mal entusiasmo divino.” “Não será um só Jesus (interrogava) o que morre pelos bons, e o que acoita os maus?" 
Nem toda ira lhe parecia maldade:

"porque a ira, se, às mais das vezes, rebenta agressiva e daninha, muitas outras, oportuna e necessária, constitui o específico da cura. Ora deriva da tentação infernal, ora da inspiração religiosa. Comu mente se acende em sentimentos deshumanos e paixões crueis; mas não raro flameja do amor santo e da verdadeira caridade. Quando um braveja contra o bem que não entende, ou que o contraria, é ódio, iroso, ou ira odienta. Quando verbera o escândalo, a brutalidade, ou o orgulho, não é agrestia rude, mas exaltação virtuosa; não é soberba đule explode, mas indignação que ilumina; não é raiva desaçaimada, mas correção fraterna. Então, não somente não peca o que se irar, mas pecará não se irando. Cólera será; mas cólera de mansuetude, cólera de justiça, cólera que reflete a de Deus, face também celeste do amor. da misericórdia e da santidade."

"Dela esfuziam centelhas, em que se abraza, por vezes, o apóstolo, o sacerdote, o pai, o amigo, o orador, o magistrado. Essas faúlhas da substância divina atravessam o púlpito, a cátedra, a tribuna, o rostro, a imprensa, quando se debatem, ante o pais, ou o mundo, as grandes causas humanas, as grandes causas nacionais, as grandes causas populares, as grandes causas sociais, as grandes causas da consciência religiosa. Então, a palavra se eletriza, brame, lampeja, atrôa, fulmina. Descargas sôbre descargas rasgam o ar, incendeiam o horizonte, cruzam em raios o espaço. E' a hora das responsabilidades, a hora da conta e do castigo, a hora das apóstrofes, imprecações e anátemas, quando a voz do homem rebôa como canhão, a arena dos combatentes da eloquência estremece como campo de batalha, e as siderações da verdade, que estala sôbre as cabeças dos culpados, revolvem o chão, coberto de vítimas e des- 
troços incruentos, como abalos de terremoto. Eis a cólera santa. Eis a ira divina."

"Quem, senão ela, há de expulsar do templo o renegado, o blasfemo, o profanador o simoníaco? quem, senão ela, exterminar da ciência o apedeuta, o plagiário, o charlatão? quem, senão ela, banir da sociedade o imoral, o corruptor, o libertino? quem, senão ela, varrer dos serviços do Estado o prevaricador, o concussionário e o ladrão público? quem, senão ela, precipitar do govêrno o negocismo, a prostituição pública ou a tirania? quem, senão ela, arrancar a defesa da pátria à cobardia, à inconfidência ou à traição? Quem, senão ela, a cólera do celeste inimigo dos verdilhões e dos hipócritas? a cólera do justo, crucifixo entre os ladrões? a cólera do verbo da verdade, negado pelo poder da mentira? a cólera da santidade suprema, justiçada pela mais sacrílega das opressões?

"Todos os que nos dessedentamos nesta fonte, os que nos saciamos dêsse pão, os que adoramos êsse ideal, nela vamos buscar a chama incorruptível. E' dela que, ao espetáculo impio do mal tripudiante sôbre os revezes do bem, rebenta em labaredas a indignação, golfa a cólera em borbotões das fráguas da consciência, e a palavra sai, rechinando, esbraseando, chispando, como o metal candente dos seios da fornalha."

"Esse metal nobre, porẻm, na incandescência da sua ebulição, não deixa escória. Pode crestar os lábios que atravessa. Poderá inflamar por momentos o irritado coração, donde jorra. Mas não o degenera, não o macula, não o resseca, não o caleja, não o endurece; e, no fundo são da urna onde tulmutuam essas procelas, e donde borbotam essas erupções, não assenta um rancor, uma inimizade, uma vingança. As reações da luta cessam, e fica, de en- 
volta com o aborrecimento do mal, o relevamento dos males padecidos."

Não há, senhores, na literatura humana, página que a esta exceda em grandeza moral, beleza e verdade. Nela, Ruy se define o homem de bem, inteiriço e sem fraquezas. $O$ aborrecimento ao mal, e o relevamento dos males padecidos, de que mais se ha de tecer a alma do santo? O aborrecimento ao mal tem seu anverso no entusiasmo pelo bem, que o ódio ao mal presupõe. O relevamento dos males padecidos é, em substância, apêlo à graça divina, que se peça para os máus.

A vida inteira de Ruy se aqueceu do entusiasmo com que evangelizou o bem, e do fervor com que o buscou, fosse qual fosse o sacrifício de si mesmo, a que se expunha.

Considerai, entre tantos outros, em primeiro lugar, êste facto. Mal se haviam inteirado três anos", de formado em direito, quando the faleceu o pai, onerado de encargos. Facílimo lhe "era evitar o peso dessa herança; bastava renunciar a sucessão a benefício do inventário"

Mas o dever lh'o vedou. Renuncia, mas é o activo da herança, em favor da irmã, e substitue nos bancos, sem reserva de condições" a firma de seu pai pela sua. Não pedira misericórdia, não a tiveram para com êle. "O morto, fôra Ruy no Senado, certa 'vez, obrigado a lembrar, em defesa de sua honra: "o morto continuou a viver em mim, nas suas responsabilidades, pelas quais nunca encontrei quartel. Era assim que eu queria; foi assim que me trataram os estabelecimentos. E assim foi que eu vencí."

E levou doze anos, pagando, mês por mês, as dividas herdadas. "Durante o longo espaço de doze anos", que the "absorveram toda a mocidade", enquanto outros se atiravam "à exploração dos casamentos opulentos", Ruy entrou na arena da vida "por um caminho coberto de obstáculos esmagadores", resgatando os "títulos do débito inevitável" $\mathrm{E}$, acumulando a sua tarefa profissional a da imprensa, a 
que se dava gratuitamente, conseguiu, ainda, dar estado à irmã, constituir nova família, a que assegurou "sempre a abastança, a decência, o conchego, o gôsto das existências distintas, a arte modesta do lar iluminado pela poesia dos afectos que se criam no trato das cousas delicadas, enquanto, par a par, sem a menor impontualidade, remia gradualmente os encargos de honra" de seu pai.

Quantos, entre os homens, entre os mais considerados, seriam capazes de sacrificar os doze primeiros anos de sua mocidade, três anos apenas de formados, para "selar a existência moral" do nome do pae, assumindo-lhe e honrando-lhe, depois de morto, o compromisso das dívidas?

Mas Ruy era assim por índole. Tinha de ser assim em toda a vida. Sempre o sacrifício pessoal pelo dever, pelos princípios, pelo bem.

Mais tarde, já no cenário da política militante, continua assombrando os homens de seu tempo, com o exemplo de sua desambição, por amor do que deva ser, e não do que pompeia em triúnfo, por aí além. Desta desambição, evocarei algumas amostras.

Nos últimos mêses da Monarquia, Ouro-Preto, com a apôio do Imperador, lhe oferece a pasta do Império. Mas Ruy andava pregando a Federação, como sistema de Estado. que mais convinha ao progresso do país. Ouro-Preto lhe concede a descentralização ampla, como caminho para o sistema federativo. Mas, em carta ao Visconde, em 7 de junho de 1889, Ruy declara:

“Infelizmente subsistem no meu espírito, cada vez com mais força, os motivos que, há uma hora, expedí a V. Excia., declarando-lhe não poder aceitar honra tão superior ao meu merecimento. Não posso ser membro de um Ministério que não tome por primeira reforma a federação." 
Regeita a honra, nada regeitável, que três vezes lhe é oferecida, por não querer amarrar "a trouxa" de suas "convicções, por amor de um ministério". Antes, por amor dos principios que lhe formam a consciência, entrouxa, desdenha e despreza os ouropeis de ministérios.

Em dezembro de 1889, Deodoro o nomeia vice-chefe do Govêrno Provisório. Ruy recusa o lugar, indicando o nome de Floriano. "Conheço as finezas que lhe devo, dizia Floriano em março de 1891, em carta a Ruy, e jamais serei ingrato." Não obstante, quando Ruy defende a Constituição contra o golpe de não proceder Floriano eleição para dar sucessor a Deodoro, que renunciara no primeiro biênio, Florıano lhe cassa as honras de general, o persegue, o arruina e o expatria.

Ruy, bem-querido de Floriano, podendo, dêle colher todas as vantagens da amizade e gratidão, não transige com a deposição dos governadores, que Floriano ordenou, com a iíegitimidade do poder, que Floriano usurpou, com o desrespeíto da Constituição e das leis, em que Floriano se desmandou. $\mathrm{E}^{\prime}$ que, acima de seus interesses pessoais, Ruy põe a evangelização das grandes causas, pelo bem de todos.

Já então resignara sua cadeira de senador pela Baía. Esta renúncia é um dos traços da coerência de Ruy. Revela, mais uma vez, o desinteresse, a desambição, a lição, pelo exemplo, de acatamento aos princípios. Ainda faltavam cinco anos, para terminar o mandato, e poderia fruí-los calmamente, como o fizeram companheiros seus do Govêrno Provisório. Já era senador, quando se promulgou a Constituição de 1891, e foi esta que taxou de inelegiveis os ministros de Estado. A proibição, porém, não podia ter efeito retroactivo.

Mas, por um dever moral, Ruy preferiu resignar o lugar de senador ainda por cinco anos, perdendo, além do estipêndio, o amparo das imunidades parlamentares.

Foi sempre assim o espírito dêste predestinado: o sacrifício dos interesses pessoais pelos interêsses da pátria. Quan- 
do se tratava de uma causa de ordem geral, Ruy estava na estacada, esquecido de si mesmo. E' a característica dos santos: quando se trate da causa de Deus, o santo está na linha da frente, sem temor, nem resguardo.

Em defesa das instituições do país, por devoção à pátria, no amor do próximo, Ruy recusa ser ministro de Pedro II, repele a vice-chefia do Govêrno Provisório, desapreça as bôas graças de Floriano, abre mão de cinco anos de senatoria, não se habitua ao caminho do Catete, e vai, mais tarde, desautorizar sua candidatura à presidência da República, por imperativos de consciência, ensinando, sempre, pelo exemplo, a supremacia dos princípios sôbre o egoismo.

De bondade espontânea, entre tantas demonstrações, talvez ignorais esta: foi nos primeiros dias da revolta de 15 de novembro, quando se esboçara uma reação militar, em Santa Catarina.

"No meu caminho para o Tesouro, nos conta Ruy, passei pela casa do chefe do Estado, situada então bem perto aqui de nós, e ouvi de S. Excia., com a comunicação dêsse fato, a notícia de que havia mandado executar os oficiais comprometidos. Não estava acostumado a estas ações de rápida energia; dirigí-me ao Tesouro impressionado. Pús, em breve carta, dirigida ao Marechal Deodoro, as minhas impressões. Ao voltar nessa mesma tarde, tive o inenarrável prazer de ouvir o nosso ilustre chefe dizer:

"Suas ordens foram cumpridas. Telegrafei para que não se consumasse a execução".

A indignação de Ruy contra a maldade, em qualquer de suas formas, irrompia espontânea. Com êle podiam contar para as bôas causas. Nunca "para a injustiça, para a ilegalidade, para a opressão, para as violações do regime constitucional". À estranheza de que em política, com Ruy não se podia contar, replica: 
"quando se necessite de um homem que não minta, que não bajule, que aconselhe com sinceridade, que não suba as escadarias da administração para lhe solicitar as mercês, mas não lhe recuse, nas grandes ocasiões, a carregar com as responsabilidades, então é comigo, e não com êsse que se há de contar. Isto é o que estou sendo, continua êle expondo, o que sempre fui, o que hei de ser, enquanto Deus, cuja misericórdia tem sido tanta comigo, me não prive de minha identidade moral. Não sou dos que acompanham os govêrnos a despeito de tudo. A despeito de tudo, só acompanho a minha consciência. Mas, estando com ela, então o amigo com quem me acho, a causa a que sirvo, me têm a seu lado."

Sua norma era praticar o bem, sem olhar a quem. Defendia inimigos com o mesmo ardor com que amparava a causa justa de um filho. Não lhe importavam as pessoas, mas os princípios. Não se temia da derrota, mas da cobardia de emudecer. Quando, em 1909, empreendeu a fundo a campanha civilista, sabia que a derrota, na apuração eleitoral, seria o termo da luta, que ia travar. Mas o bem da pátria, a ordem civil, a nação a postos para a escolha de seu presidente, a reação civil contra a substituição das urnas pela espada, suplantou, nêle, quaisquer considerações de ordem interesseira.

Quando Floriano reforma generais e almirantes, por terem reclamado, em obediência à lei, a eleição do sucessor de Deodoro; quando prende senadores e deputados contra as imunidades parlamentares; quando demite contra a lei professores vitalícios, entre os quais Seabra, e deporta os presos para lugares longínquos, no rigor do estado de sítio, que decretou, Ruy, "sentindo vacilar, sôbre suas bases, o edifício do direito constitucional que lhe custara tanto a criar", e "compreendendo que, se um forte exemplo de resistência imediata não chamasse à ação os órgãos reparadores, estava fundado 
o absolutismo", apela para o Supremo Tribunal Federal, na série dos habeas-corpus de 92 a 93 .

A 18 de abril de 1892, impetra o primeiro habeas-corpus para os presos do sítio. Era a primeira vez que o Supremo Tribunal Federal iria, no regime republicano e presidencialista, que se ensaiava, dar prova da grande tarefa que a Constituição lhe atribuira. E, a 23 de abril, fala ao Supremo Tribunal, nêsses termos:

"Nós, os fundadores da constituição, não queríamos que a liberdade individual pudesse ser diminuida pela fôrça, nem mesmo pela lei. E, por isso, fizemos dêsse Tribunal o sacrário da Constituição, demos-lhe a guarda da sua hermenêutica, pusemô-lo como um veto permanente aos sofismas opressores das razões do Estado, resumimos-lhe a funçäo especifica nesta idéia. Se ela vos penetrar e apoderar-se de vós, se for, com nós concebiamos, como os Estados Unidos conseguiram, o princípio animante dêste Tribunal, a revolução republicana, estará salva. Se, pelo contrário, se coagular, morta, no texto, como o sangue de um cadáver, a constituição de 1891 está perdida."

o Supremo Tribunal Federal, naquele momento histórico, falhou.

Porque, expõe Ruy:

"Havia, no Tribunal, ao cair dos votos que denegaram o "habeas-corpus", a impressão trágica de um naufrágio, contemplado a alguns braços da praia, sem esperança de salvamento; de uma grande calamidade pública, que se consumasse, sem remédio, aos nossos olhos; de uma sentença de morte sem apêlo, que ouvíssemos prinunciar contra a pátria; do bater fúnebre do martelo, pregando, entre as quatro tábuas de um esquife, a esperança republicana." 
Houve, porém, um juiz, cujo nome é preciso repetir aos moços, um juiz paulista, Piza e Almeida, que, compreensivo e sem temor, concedera o que os seus colegas acabavam de recusar.

“Toda a grandeza dessa causa, diz Ruy, que há de levantar-se na história de meu país, como uma altura coroada de luz, quando as misérias de hoje tiverem passado, no movimento que leva para o olvido os restos erráticos das paixões dos homens e do infortúnio dos povos, figurou-se-me humanada, naquele homem modesto, silencioso, em cuja fisionomia, suave e triste, como as lendas crentes querem que fosse a do Salvador, a expressão da timidez e da doçura, dir-se-ia um disfarce divino da justiça, da inquebrantabilidade, da coragem moral. E disse comigo: "Nesta crise de pigmeus, ainda nos restam gigantes." Vendo perder-se tudo pela distensão de todas as molas morais dentro e fora da política, refletí entre mim: "Seis homens desta têmpera comporiam o alicerce da República e salvariam a Pátria."

Mas nem a pátria, a quem Ruy dava tudo, fugiu à regra triste da incompreensão e da ingratidão. Em conseqüência de seu apêlo à justiça, em defesa da Constituição, teve de refugiar-se no estrangeiro. Nenhum interêsse pessoal tinha tido na defesa das vítimas de Floriano. Inspirava-o o bem de todos, o império da lei sôbre a paixão dos homens. Mas a paga, como a de Christo na cruz, foi a perseguição, o desemprêgo, o exílio.

Não se albateu, porém. Sua posição, nêste mundo de mistérios, tinha de ser a de plantar o carvalho para o abrigo do futuro.

A campanha civilista, depois da glorificação de Haya, neroe pela devoção à luta, na certeza de que a política lhe escamotearia a vitória das urnas, foi uma das memoráveis 
lições de sacrifício pessoal pela realidade da democracia entre nós. Seu competidor era inelegível, e não foi eleito. Mas o Congresso Nacional proclamou eleito o inelegível, e derrotado o eleito. Foi uma das mais tristes provas da inprevidência da Constituinte, quando incumbiu ao Congresso o exame das actas eleitorais de todo o país, para proclamar o eleito presidente. A conseqüência foi o Congresso arbitrário usurpar à Nação, confiada e desprevenida, a prerrogativa de nomear seú primeiro magistrado.

Mas Ruy, espoliado, não ensarỉha as armas. Continua na evangelização dos bons princípios. No fim do govêrno Hermes, a política reinante, que êle combatera sem tréguas, parece arrependida da hostilidade que the movera, e lhe of erece a candidatura à presidência, com apôio do marechal.

Estávamos em 1913. Pinheiro Machado se empenha em lançar a candidatura de Ruy, com uma só condição: a de nẩo insistir Ruy na revisão constitucional.

Ora, Ruy levantara, há muito, a bandeira revisionista. A Constituição de 1891, ainda hoje a melhor de quantas tivemos, estava inçada de defeitos graves. De um dêles, a eleição do presidente, quando a vaga se dava no primeiro biênio, já se experimentava, como resultado, a revolução civil de 1893. De outro, a eleição direta em um só grau, com a missão congressual de proclamar o eleito, dera na usurpação militarista de 1910, e, por estas e outras razóes, clamava Ruy a nação despercebida e adormecida, para a reforma constitucional. Em memóravel discurso, na Baía, na campanha civilista, Ruy enumerara os pontos essenciais de revisão entre os quais o voto secreto.

Poderia uma consciência, como e de Ruy, calar as reindicações que proclamava, só porque lhe ofereciam, com a certeza da vitoria, a presidência da República?

Pinheiro Machado incumbira a Vilaboim, professor desta Casa, e a Francisco de Castro Filho, a promoção de um entendimento com Ruy. Mas Ruy, sempre fiel a sua cons- 
ciência, rejeita a sujestão de uma entrevista à imprensa, em que não insistisse nas emendas constitucionais.

"Eu sou um programa, fez êle ver, e seu primeiro ponto é a revisão."

Não poderia dêle esperar outra resposta quem não tivesse o vezo de jalgar os outros por si. Ruy foi, nêste pobre país, sempre e sempre, o grande desconbecido. Não o compreendiam Francisco de Castro Filho, amigo tradicional da casa de Ruy, Vilaboim, o espírito arguto desta Faculdade, Pinheiro Machado, o chefe de altas qualidades na guerra e na paz, amigo de Ruy, de quem dissera:

"Jamais procurarei diminuir a altura do vôo daqueles que sabem e têm o poder de fitar a própria luz do sol."

E sôbre quem opinara:

"Sempre tive S. Excia. como homem de grande coragem, para enfrentar, sem vacilações, nem temores, as responsabilidades que por ventura the caibam na vida pública".

Pois êstes homens, que privaram com Ruy anos seguidos, que lhe sentiram a sinceridade em lutas ásperas, que o viram sempre na vanguarda e no mais acêso das batalhas pelo direito e pela liberdade, onde quer que estivesse a violência, fosse pelo beneficio de quem fosse, amigo ou inimigo, nobre ou degradado, êstes homens era preciso não conhecerem a Ruy, para lhe irrogarem a afronta de o supôr capaz de aceitar a presidência da República, com arranhões na consciência, como seria a renúncia a seu programa revisionista.

Bem se definia Ruy, quando a si mesmo declara:

"Valho apenas o que fui, e o que sou: a consciência de um homem com quem todos os amigos da lei e 
da justiça sabem onde irão se encontrar, diante de quaisquer questões graves, que neste país se levantem. A êste regime não devo cousa alguma".

A afronta de lhe proporem desistência de um princípio, pelo engôdo de uma presidência da República, Ruy a repeliu, como era de esperar, e continuou o preterido de sempre.

Em 1919, reafirmava êle, em carta a Nilo Peçanha, quando de novo influências partidárias pensam em fazê-lo. candidato:

"O meu' nome é inseparável do programa revisionista." "Com êsse programa está identificada a minha candidatura. Eư sou êsse programa. E' êsse programa que a opinião pública vê na minha pessoa. Não é senão êsse programa o que em mim quer a Nação, ou alguma parte da Nação me quer. Até agora, a política brasileira quer a Constituição inalterada para a violar; eu a quero reformada, para a conservar."

Não demorou muito, que esta mesma política, vezeiramente anti-revisionista, não só fez a revisão em 1926, mas, ainda, deitou por terra, na revolução de 1930, a obra monumental de 1891. E, depois, preferiu o absolutismo, não querendo outra nenhuma constituição, o que levou São Paulo, em 1932, a inscrever, em sua história, a grande página de idealismo político, em dias memoráveis.

Dir-se-ia que Ruy não era bom político. Se queria a revisão, bastava calar, ser eleito, e, depois, fazê-la. E' êle mesmo quem o diz:

"Bem sei que, em política, há outros caminhos, de que eu me poderia valer com segurança. A astúcia me indicaria não mexer com essa dificuldade, assenhorear-me do poder, e, com os meus recursos, 
eleger uma legislatura amarrada ao compromisso de me dar a reforma constitucional."

Mas sua consciência não se coadunava com a dobrez da astúcia. Não the aprazia, declara, "manipular a eleição de um congresso, tentando a reabilitação do regime com a exploração dos mesmos abusos que o têm prostituido." Seria processo de baixa politicagem, que repugnava a quem os fins não justificam os meios.

Os meios hão de ser em si mesmos nobres, como os fins que pretendam. Só por míngua de sentimentos puros, o homem realiza o bem, praticando o mal. 0 bem, para as almas de escól, só com o bem se hả de buscar.

E' rejeitou, pela segunda vez, receber dos mandões políticos, a presidência da República, só porque não lhe aprouve trocar a voz de sua consciência, tão cheia de entraves, pela astúcia que vence, como a serpente, no paraiso, a pobre Eva inexperiente.

A alma de Ruy era:

"daqueles em quem o dever sobrevive à esperança, e a paixão do bem substitui, com vantagem, a confiança da vitória."

Para Ruy

"o mais esquisito dos prazeres é o que Deus pôs na satisfação de abraçar a justiça condenada, condenando-nos, com ela, ao revés antecipado."

Para êle:

"a fortuna passa, o egoismo envelhece, e, afinal, das vitórias sinistras da iniqüidade, emerge o astro polar das regiões do futuro, para cujos abismos cristalinos, para cujas imensidades silenciosas, bendito seja o 
Criador por nos ter dado com o instinto divino lançar a âncora da fé."

Apenas mais dois episódios de sua vida, tão refulgente de beleza moral.

Em 1918, Ruy, embora em paz com a situação da Baía, não resiste ao "grito de angústia e desespêro" de jornalistas de sua terra, agredidos pela policia baiana. Apelaram em telegrama para Ruy. E Ruy acode:

“Eu que nunca cortejei a ídolos, mas me devotei sempre aos princípios, às verdades, às realidades políticas na sua essência, na sua substância, não podia recusar o meu apôio, embora inútil, o meu protesto, embora ocioso, aos meus patricios feridos nos mais elementares de seus direitos, à minha terra natal, prejudicada nas mais essenciais garantias de sua existência."

Desta sua atitude resultou que seu filho, Alfredo Ruy, perdeu a cadeira de deputado pela Baía. Insistiram, em casa, com Ruy, para lhe suavizar a atitude, na esperança de salvar a candidatura do filho. Depõe João Mangabeira:

"Tudo inútil. Uma noite, após o jantar, presenciei D. Maria Augusta suavemente intervir. E assim ela falou: "Você já respondeu no Senado, já falou duas vêzes. Poderiam deixar de falar amanha." E Ruy incontinenti: "Não há hipótese de não falar. Em defesa da liberdade, não recuei de Floriano. E era Floriano meu amigo. Quanto mais de Seabra." E. D. Maria Augusta: "Não, Ruy, não é isso; é que você está doente." Realmente estava. E êle textualmente: "Que morra. Morrerei bem. Morrerei na tribuna, defendendo a liberdade da imprensa em minha terra." E como dissesse estas palavras em tom um pouco alto, D. Maria 
Augusta, acto continuo, num gesto de carinho, passou-lhe a mão pela cabeça, e beijando-o na fronte: "Não se zangue, Ruy. Você tem razão. Não deixe de falar".

E falou. E o filho perdeu a cadeira de deputado pela Baía, em desforra da atitude do pai, que defendia com abnegação a liberdade de imprensa.

Por fim, a última lição, quase na hora da morte. Tratava-se da sucessão governamental na Baía, com Arthur Bernardes na presidência da República. Em Petrópolis, em sua casa, reunidos os amigos, para combinar uma candidatura, Ruy recebe uma carta de Aureliano Leal, candidato, justificando seu não-comparecimento à reunião, com esta declaração intempestiva:

“O meu pensamento será o de não criar embaraços a qualquer combinação que satisfaça plenamente a S. Ex., o Sr. Presidente da República."

Sempre a eterna ignorância de quem era Ruy, o grande desconhecido neste país, a quem servira sempre como ninguém. Ruy, semi-agonizante, se transfigura: "Contesto ao presidente da República indicar candidatos aos governos estaduais." Não renegaria os principios por que se batera em toda a vida. E, durante cerca de vinte minutos, a eloqüência, a sinceridade, a superioridade moral dêste homem, sem igual neste praís, lhe consumiram os restos de vida, ensinando, com aquele exemplo derradeiro, mais do que com a doutrinação, "o culto da lei, o exercício da liberdade, a prática da democracia."

Morreu combatendo pelo bem de seus semelhantes.

Ao delinear êste esboço Ruy, homem de gênio e homem de bem, eu não me livro, ainda agora, da sensação de quem perdeu o fôlego antes da meta. São tantas as manifestações da generosidade e da grandeza moral de Ruy, 
na longa vida, de que lhe fez Deus mercê, que mal se podem aflorar, no espaço de uma aula, alguns episódios expressivos. Dar-me-ei por feliz, se o bastante para vos dar a ver, no aspecto moral, o traço dominante de sua vida: o sacrifício de si mesmo pelo bem do próximo.

A devoção aos princípios, sangrando entre espinhos, foi o lema que o extremou da época em que viveu, e de todos, a quem serviu. As ingratidões daqueles a quem mais beneficiou, não o esmoreciam na luta ardorosa e espera pelo bem da pátria e da hunıanidade. A inveja não perdoa, em ninguém, superioridade de que não seja capaz. Mas a cada maldade, a cada represália, a cada preterição, Ruy terminava perdoando:

"Nesta alma tantas vezes ferida, relembra êle com doçura e melancolia, e traspassada tantas vezes, nem de agressões, nem de infamações, nem de ingratidões, nem de perseguições, nem de traições, nem de expatriações, perdura o menor rastro, a menor idéia de vindicta. Deus me é testemunha de que tudo tenho perdoado. E, quando lhe digo, na oração dominical: "Perdoai-nos, Senhor, as nossas dívidas assim como nós perdoamos aos nossos devedores", julgo não lhe estar mentindo; e a consciência me atesta que, até onde alcança a imperfeição humana, tenho conseguido, e consigo todos os dias, obedecer ao sublime mandamento. Assim me perdoem também os com quem houver sido injusto, violento, intolerante, maligno ou descaridoso."

O sacrifício de si mesmo pelo bem do próximo, a paciência para suportar as perseguições, o perdão das afrontas imerecidas, e, apesar de tudo, a pertinácia desta devoção até os últimos instantes da vida, que mais (se perguntará com razão) caracteriza a santidade neste mundo? Retirae da alma dos bem-aventurados êstes atributos, e da 
benemerência que os santifique, nada lhes restará, que valha.

Amar ao próximo, como a si mesmo, resume, certo, a santidade. Não, o amor abstrato, o amor contemplativo, o amor de rezas. Mas amor em actos, como a caridade de São Vicente de Paulo, o sacrifício real, como o dos que deram a vida pela fé, o perdão sem amargura, como na doutrina cristã. Assim foi Ruy em toda sua vida.

Mais que inteligência prodigiosa, mais que cultura extensa e profunda, mais que capacidade infatigável de trabalho, o que, acima de tudo, se admira e se aplaude, em Ruy, é a coragem das atitudes, a grandeza d'alma, que o singularizou, a santidade que o inspirou na vida, apostolando, esquecido de si, sem descanço, dia a dia, mais com o exemplo que com a pregação, o respeito ao direito e o exercício da liberdade, o dever acima dos interesses, a pureza da vida acima dos triunfos materiais, numa constante paixão da verdade e do bem.

São estas duas atitudes, a da verdade e a do bem, que aperfeiçoam, na criatura, a obra do Criador.

Discípulos que sois, ou ides ser, do direito que aqui se prega; cavaleiros que sois, ou ides ser, da liberdade, que aqui se axalta, não haveis, deixando esta Casa, de buiscar rumos na filosofia da fôrça, sem o timo do futuro, nem. senso moral, a filosofia do sofisma em que se debate, hoje em dia, o mundo. Na vida pública, onde tendes papel de representar, o destino vos acena, ou já vos alcança nos braços de um dilema: ou estareis aparelhados para o sacrifício de vós mesmos, por amor da liberdade e do direito; ou levais em mente sacrificar o direito e a liberdade, por amor de vós mesmos.

Ou proximidade de Ruy, ou a vala comum.

O mistério se desvendará, mais dias, menos dias, de cabeça erguida, como visitante ousado, em vossa casa. E, então, ou vos sentireis iluminado para a glória de não fazer 
a ninguém o que não quereis que vos façam, antes fazer aos outros o que desejais para vós; ou, pelo contrário, sentirvos-eis fascinados nas pompas da vaidade para o éxito de vós mesmos, fazendo, a qualquer preço, de seja quem fôr, carne de canhão para vossas ambiçöes.

Escolheis, e, nas extremas, ou sereis, em seguimento de Caim, um proscrito; ou, nas alturas, como Ruy, eleitos do Senhor. 